Frederik KORTLANDT

Leiden University

\title{
SHORTENING AND METATONY IN THE LITHUANIAN FUTURE
}

Daniel Pe t it has recently discussed the distribution of shortening and metatony of the acute tone in the $3^{\text {rd }}$ person forms of the Lithuanian future tense (2002). He rejects the traditional view that shortening is regular in polysyllables and metatony in monosyllables and proposes that shortening affected stems with acute monophthongs while metatony affected stems with acute diphthongs. In fact, the latter distribution is evident from the $1^{\text {st }}$ and $2^{\text {nd }} \mathrm{sg}$. endings $-\grave{u}$, $-\grave{i}$, which represent earlier monophthongs

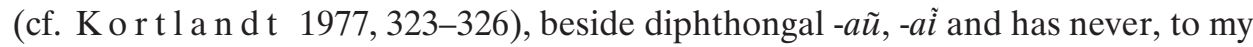
knowledge, been questioned for polysyllabic word forms. It follows that the disagreement is limited to monosyllables with $\dot{y}, \hat{u}, \hat{\imath} e, u ́, o, e ́, o ́$ in the root. The difference

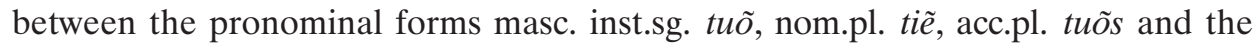
corresponding adjectival forms gerù, gerì, gerùs supports the traditional view that metatony is regular in monosyllables and shortening in polysyllables. It remains to be explained how the shortening in monosyllabic roots and the spread of metatony to suffixal monophthongs in polysyllabic stems originated.

In the standard language, which is based on a western Aukštaitian dialect, shortening is limited to the high vowels $y, \hat{u}$ in a part of the monosyllabic roots. S e $\mathrm{n} n$ lists the following instances $(1966,231)$ :

1. vocalic roots: shortening in (at)gýti, (su)lýti, rýti, búti, džiúti, griúti, púti, žúti, metatony in výti, siúti;

2. consonantal roots: shortening in dýgti, plýšti, išvýsti, lúžti, rúgti, slúgti, metatony in výsti, (su)lýsti, (at)lýžti.

All other verbs show metatony, which is also spreading in the category of consonantal roots listed here. It is therefore reasonable to assume that the high vowels $y$ and $\bar{u}$ were shortened in monosyllables whereas íe, úo, é, ó were subject to metatony. This is in agreement with the shortening in the pronominal forms fem. nom.sg. $\grave{s}, j \grave{i}$ and $1^{\text {st }}$ and $2^{\text {nd }}$ person acc. pl. mùs, jùs.

Thus, the disagreement about the original distribution of shortening and metatony is now limited to monosyllabic verbs with íe, úo, é, ó in the root, for which Petit assumes shortening instead of metatony. This assumption deprives him of the possibility to explain the pervasive metatony in the polysyllabic verbs in -ýti, -éti, -óti, -úoti, which make up the large majority of verbs in Lithuanian. The massive spread 
of metatony cannot possibly be attributed to the influence of such verbs as gyvénti and vadinti. It requires a far more frequent model, which is found in simple root verbs like déti, jóti, dúoti. This is in fact corroborated by the shortening instead of metatony in polysyllabic verbs in -ýti in the southern and eastern Aukštaitian dialects, e.g. darìs, rašìs, sakìs (cf. Z i n k e vi č i u s 1966, 361; K ort l a n d t 1985, 115). In the easternmost Aukštaitian dialects metatony was wholly eliminated and the shortening even spread analogically to circumflex roots and to the imperative and conditional moods (cf. Zi n keviči u s 1966, 362).

There remains a chronological problem because Leskien's shortening and metatony were comparatively recent developments (cf. K o r t l a n d t 1977, 328), which leaves little time for the massive spread of metatony in polysyllabic verbs. I therefore think that the metatony in verbs in -éti, -óti, -úoti is an older development which preceded Leskien's law (cf. already Ko r t l a n d t 1975, 86 and 1985, 115). It was analogical after the loss of the acute tone in dẽs, jõs, duõs, liẽs which resulted from the early Balto-Slavic loss of a laryngeal after a Proto-Indo-European long vowel in monosyllables. The same development gave rise to the circumflex tone of Latvian sà̀ls, gùovs and Lithuanian -dẽ in arklìde, avìdé, alùdè, pelùdé, žvaigždẽe, which was generalized in the nom.sg. form of the $\bar{e}$-stems (cf. Kortla n d t 1985, 118$120)$. Contrary to Petit's statement $(2002,262)$, this analysis is not based on a comparison with Slavic but on the internal East Baltic evidence. Note that Latvian has preserved the acute tone in the pronominal forms tiẽ and ši

\section{REFERENCES}

K o r t l a nd t F., 1975, Slavic Accentuation: A Study in Relative Chronology, Lisse.

K ort la n d t F., 1977, Historical Laws of Baltic Accentuation, - Baltistica, XIII (2), 319-330.

K o r t l a nd t F., 1985, Long Vowels in Balto-Slavic, - Baltistica, XXI (2), 112-124.

P e t it D., 2002, Abrègement et métatonie dans le futur lituanien: pour une reformulation de la loi de Leskien, - Bulletin de la Société de Linguistique de Paris, IIIC (I), 245-282.

S e n n A., 1966, Handbuch der litauischen Sprache, I. Grammatik, Heidelberg.

Z i n k e viči u s Z., 1966, Lietuvių dialektologija. Lyginamoji tarmių fonetika ir morfologija, Vilnius. 